Research.

\title{
INTERNAL CONTROL SYSTEM ANALYSIS ON ACCOUNT RECEIVABLES IN E-RN TRADING BUSINESS
}

\author{
Nicholas Renaldo $^{1^{\star}}$, Sudarno ${ }^{2}$, Marice Br. Hutahuruk ${ }^{3}$, Suyono ${ }^{4}$, Suhardjo ${ }^{5}$ \\ Institut Bisnis dan Teknologi Pelita Indonesia ${ }^{1,2,4,5}$, Institut Teknologi dan Bisnis MASTER ${ }^{3}$ \\ nicholasrenaldo@lecturer.pelitaindonesia.ac.id ${ }^{1 *}$, \\ sudarno@lecturer.pelitaindonesia.ac.id², mrctalenta@yahoo.com ${ }^{3}$, \\ suyono@lecturer.pelitaindonesia.ac.id ${ }^{4}$, suhardjo@lecturer.pelitaindonesia.ac.id ${ }^{5}$
}

\author{
${ }^{*}$ Corresponding author \\ Received: August 11, 2021 Accepted: November 21,2021 Published: December 29, 2021
}

To cite this article: Renaldo, N; Sudarno; Hutahuruk, MB; Suyono; Suhardjo (2021).Internal Control system analysis on account receivables in E-RN trading business. The Accounting Journal of BINANIAGA. 6 (2), 81-92 doi:10.33062/ajb.v6i2.455

\begin{abstract}
Large bad debt will disrupt cash flow in the business. This study aims to determine how the implementation of COSO-based internal control in the E-RN Trading Business. This research was conducted in Pekanbaru City, Riau. The data used in this study are primary data and secondary data. Collecting data using observation techniques, interviews, literature studies, and questionnaires. The research method uses descriptive analysis, binomial test, and sign test. The test results show that the control environment, risk assessment, and supervision and monitoring have not been effective in the E-RN Trading Business, but control activities and information and communication have been running effectively in the E-RN Trading Business. Overall testing shows that the implementation of the E-RN Trading Business internal control system is still less effective. Recommendations for E-RN Trading Business implements policies to limit and monitor employee actions so as not to deviate, comply with existing regulations and policies, and improve employee performance, conducts an analysis beforehand and pays attention to receivables, regularly holds meetings after a problem is discovered, and conducts unannounced checks once a week so that fraud does not occur.
\end{abstract}

Keywords: Account Receivables, COSO, Internal Control, Sign Test

\section{INTRODUCTION}

In a trading company, sales are an important element because it becomes a cog in the company's business continuity where the company gets cash that will be used to support operational activities. Therefore, a strategy is needed to increase sales so that the goods we offer can be recognized and survive in market competition. Credit sales are one of the sales strategies that are widely used by companies today to increase their sales volume.

Credit sales are carried out by the company by sending goods in accordance with the order received from the buyer and for a certain period of time the company has a bill to the buyer. Credit sales do not immediately generate cash receipts, but generate accounts receivable from customers so that on the day of maturity the company collects and the customer pays off the receivables, then there is a cash inflow from collecting the receivables.

Nicholas Renaldo; Sudarno; Marice Br. Hutahuruk; Suyono; Suhardjo. Internal Control System Analysis on Account Receivables in E-RN Trading Business 
For this reason, credit sales are riskier than cash sales because, in credit sales, customers can be slow or not pay their receivables, causing uncollected receivables and even being the risk of bad debts in the future. To avoid this risk, a good internal control of accounts receivable is needed.

With the existence of internal control, it is expected that there will be a supervision of the company's operational activities such as credit sales and management of receivables. Although internal control cannot guarantee that all errors and fraud can be eliminated, it is expected to minimize the opportunities for errors and fraud to occur. Even if there is an error and fraud, with good control it will be immediately identified so that it can be addressed quickly and accurately.

E-RN Trading Business (E-RN TB) is an importer trading company that is engaged in the distributor of motorcycle spare parts sales from the People's Republic of China (PRC) factory. Its business activity is to distribute motorcycle spare parts imported from China to shops or consumers who sell motorcycle spare parts. In sales, E-RN TB makes sales in cash and credit, so that in credit sales it creates a fairly large amount of trade receivables.

However, there are obstacles in the collection of receivables, where receivables are due and should be paid off by the customer but have not yet been paid. Even though there are payments, sometimes they only pay in installments, leaving uncollected receivables on the invoice in question. This is a problem where uncollected receivables are piling up from time to time and it is feared that there will be a risk of becoming uncollectible accounts in the future.

Data regarding reports of receivables on E-RN TB as of December $31^{\text {st }}$ each year is shown in table 1.

Table 1. Recapitulation of Receivable Reports of E-RN TB for the 2016-2020 Period

\begin{tabular}{ccccc}
\hline Year & $\begin{array}{c}\text { Total } \\
\text { Receivables }\end{array}$ & $\begin{array}{c}\text { Accounts } \\
\text { Receivables }\end{array}$ & $\begin{array}{c}\text { Uncollectible } \\
\text { Receivables }\end{array}$ & $\begin{array}{c}\text { Percentage of } \\
\text { Uncollectible Accounts }\end{array}$ \\
\hline 2016 & 9.564 .763 .059 & 8.773 .890 .880 & 790.872 .179 & $8,269 \%$ \\
\hline 2017 & 11.669 .594 .866 & 10.477 .360 .004 & 1.192 .234 .862 & $10,217 \%$ \\
\hline 2018 & 12.302 .058 .153 & 11.629 .119 .623 & 672.938 .530 & $5,470 \%$ \\
\hline 2019 & 11.974 .000 .759 & 11.508 .892 .022 & 465.108 .737 & $3,884 \%$ \\
\hline 2020 & 13.596 .260 .541 & 12.590 .352 .080 & 1.005 .908 .461 & $7,398 \%$ \\
\hline Total & $\mathbf{5 9 . 1 0 6 . 6 7 7 . 3 7 8}$ & $\mathbf{5 4 . 9 7 9 . 6 1 4 . 6 0 9}$ & $\mathbf{4 . 1 2 7 . 0 6 2 . 7 6 9}$ & $\mathbf{6 , 9 8 2 \%}$ \\
\hline Sour &
\end{tabular}

Source: E-RN Trading Business, 2021

From table 1 it can be seen from the percentage of bad debts each year the amount fluctuates but the value is quite large. The following is a report regarding the analysis of the age of uncollected accounts receivable at E-RN TB per year.

Table 2. Age of Uncollected Receivables Report on E-RN TB Period 2016-2020

\begin{tabular}{cccccc}
\hline Year & 1-30 Days & 31-60 Days & 60-90 Days & >90 Days & $\begin{array}{c}\text { Total Uncollectible } \\
\text { Accounts }\end{array}$ \\
\hline 2016 & 97.545 .643 & 82.017 .546 & 142.649 .748 & 468.659 .242 & 790.872 .179 \\
\hline
\end{tabular}




\begin{tabular}{cccccc}
\hline Year & $\mathbf{1 - 3 0}$ Days & $\mathbf{3 1 - 6 0}$ Days & $\mathbf{6 0 - 9 0}$ Days & >90 Days & $\begin{array}{c}\text { Total Uncollectible } \\
\text { Accounts }\end{array}$ \\
\hline 2017 & 128.558 .777 & 192.158 .552 & 96.201 .418 & 775.316 .115 & 1.192 .234 .862 \\
\hline 2018 & 141.269 .214 & 142.797 .418 & 112.155 .515 & 276.716 .383 & 672.938 .530 \\
\hline 2019 & 177.287 .011 & 173.372 .302 & 102.170 .544 & 12.278 .880 & 465.108 .737 \\
\hline 2020 & 192.988 .176 & 165.916 .761 & 179.381 .696 & 467.621 .828 & 1.005 .908 .461 \\
\hline Total & $\mathbf{7 3 7 . 6 4 8 . 8 2 1}$ & $\mathbf{7 5 6 . 2 6 2 . 5 7 9}$ & $\mathbf{6 3 2 . 5 5 8 . 9 2 1}$ & $\mathbf{2 . 0 0 0 . 5 9 2 . 4 4 8}$ & $\mathbf{4 . 1 2 7 . 0 6 2 . 7 6 9}$ \\
\hline
\end{tabular}

Source: E-RN Trading Business, 2021

From table 2, it can be seen that there are still receivables that have long passed the due date but have not been paid off by consumers, so it can be concluded that bad debts always occur in each period. This also shows that there has been no effort from ERN TB to reduce the level of uncollected receivables. Good internal control should be able to minimize the problem of bad debts.

Research gaps related to internal control were carried out by (Singal \& Tirayoh, 2015), (Binanggal, 2016), (Runtu \& Elim, 2016), (Wensen, Kawet, \& Saerang, 2016), (Desantirahayu, 2017), (Renaldo, Sudarno, \& Hutahuruk, 2020), and other researchers who gave very mixed results.

With good internal control, it is hoped that it can help E-RN TB in overcoming these problems so that it does not cause too large a loss, especially since the value of large receivables cannot be collected for more than five years. Based on the phenomenon and research gap, it would be interesting to discuss the internal control of accounts receivable at E-RN TB. Thus, the aim of this research is to analyze the effectiveness of internal control on accounts receivable in the E-RN Trading Business.

\section{Identification of the Problem}

Based on the above background, the problem in this research is whether the implementation of internal control over the E-RN Trading Business' receivables has been effective or not.

\section{Problem Limitation}

Referring to the identification of the problem above, this research is limited to receivables from E-RN Trading Business.

\section{Problem Design}

The design problem in this study is to determine the application of internal control at E-RN Trading Business.

\section{Research Purposes}

Based on the formulation of the problem, the purpose of this study is to determine whether the application of internal control over the accounts receivable of E-RN Trading Business has been effective or not.

\section{Research Benefits}

It is hoped that the results of this research can be useful for the development of education both theoretically and practically. The theoretical benefit of this research will be scientific development in the field of accounting information system. This research is also useful as reading material/reference for academics and also this research can then be a reference for further researchers. Practical benefits are used as improvement materials for E-RN Trading Business to be able to run their business optimally.

Nicholas Renaldo; Sudarno; Marice Br. Hutahuruk; Suyono; Suhardjo. Internal Control System Analysis on Account Receivables in E-RN Trading Business 


\section{LITERATURE REVIEW}

\section{Accounting and Receivables}

Accounting can be defined as an information (Chandra, Renaldo, \& Putra, 2018) system that provides reports to users of accounting information on the results of the company's performance and financial condition. At first, a business transaction will be identified (analyzed), recorded, then reported through accounting reports which are a medium of communication of accounting information. Business transactions here can be interpreted as an economic event or event that affects changes in the company's financial position. Accounting is a process that starts from transactions as evidenced by invoices, then from transactions journals, ledgers, worksheets are made, then will produce information in the form of financial statements used by certain parties. Based on these two terms, it can be interpreted that accounting is a process of identifying, recording, presenting, and reporting that starts from collecting transaction data (invoices, receipts, etc.), recording into journals, ledgers, worksheets of a measurable economic event with monetary units to form financial reports that provide information in the form of financial statements that will be used by related parties (Renaldo et al., 2020).

Accounts receivable represent claims that will be repaid with money that is not supported by written promises arising from the sale of goods or services produced by the company. Accounts receivables include receivables arising from the sale of products or the delivery of services in the course of the company's normal business activities. Accounts receivable are bills that are not supported by a written promise that is only accompanied by a travel document, invoice/other receipts that have been signed by the debtor so that the statement of having received the goods is in the letters (Desantirahayu, 2017).

Accounts receivable are company invoices to customers or buyers or other parties who purchase company products. Receivables both to individuals and to other companies that will be received in the form of cash. Accounts receivable arise as a result of credit sales. Most companies sell on credit in order to sell more products or services. Receivables are receivables from credit sales that have matured to customers or other parties which after being billed or paid off will be realized into cash.

\section{Internal Control System}

Internal control has a narrow and broad meaning. The internal control system in a narrow sense (internal check term), which is a mechanical procedure to check the correctness of administrative data. Meanwhile, in a broad sense, the internal control system is seen as a social system that has different special meanings/insights within the company's organization. Accounting control systems and administrative control systems are included in the control system in a broad sense (Singal \& Tirayoh, 2015).

The internal control system consists of policies and procedures designed to provide adequate assurance for management that the company has achieved its goals and objectives (Renaldo et al., 2020). The COSO (Committee of Sponsoring Organization) model is an internal control model used by auditors as a basis for evaluating and developing internal controls. COSO considers internal control as a comprehensive set of actions within the organization. $\mathrm{COSO}$ also explained that internal control is in the process of basic management, namely planning, implementation, and monitoring. Control is not something added to the management process but an integral part of the process (Desantirahayu, 2017).

According to COSO, there are five components of internal control. The five components of internal control are (Renaldo et al., 2020):

\section{Environmental Control}

Nicholas Renaldo; Sudarno; Marice Br. Hutahuruk; Suyono; Suhardjo. Internal Control System Analysis on Account Receivables in E-RN Trading Business 
These components include management attitudes at all levels of general operations and the concept of control in particular. The control environment sets the tone for the organization, which affects the control consciousness of its members. The control environment is the basis for the other components of internal control, providing discipline and structure. The factors that shape the control environment include integrity and ethical values, commitment (Putra \& Renaldo, 2020) to competence, the board of commissioners or audit committee, management philosophy and operating style, organizational structure, empowerment and responsibility, and human resource policies and practices.

2. Risk Assessment

Risk assessment for financial reporting purposes is the identification, analysis, and management of entity risks related to the preparation of financial statements, in accordance with generally accepted accounting principles. COSO adds consideration to objectives in all areas of operations to ensure that all parts of the organization work in harmony. The factors that influence the determination of risk in internal control are changes in the operating environment, changes in the structure or composition of new personnel, development of information systems, organizational growth, and the use of new technology, development of new operations and areas of operation. and issuance of new accounting standards.

\section{Control Activities}

Control procedures are established to standardize work processes so as to ensure the achievement of company goals and prevent or detect deviations and errors. Generally, control activities that may be relevant to an audit can be classified as policies and procedures relating to performance review, information processing, physical control and asset control, adequate documentation and records, adequate segregation of duties, proper authorization of transactions and activities. and the existence of new policies to prevent risks that harm the company.

\section{Information and Communication}

The accounting system contains procedures that must be obeyed by company personnel and is able to provide accurate information to parties who need it, especially for management, and can establish communication between existing sections so that the implementation is uniform. Information systems relevant to financial reporting objectives, which include accounting systems, consist of the methods and records created for recording, managing, summarizing, and reporting entity transactions (including events and circumstances) and for holding accountability for assets, related liabilities, and equity. The quality of the information generated by the system affects the ability of management to take appropriate decisions in managing and controlling the activities of the entity to prepare reliable financial reports.

Communication involves providing an understanding of the roles and responsibilities of individuals with respect to internal control over financial reporting. Communication includes the extent to which personnel understands how their activities in the financial reporting information system relating to the work of others and how to report deviations to the appropriate level in ethnicity. The factors that affect information and communication in internal control are identification of all transactions, timely provision of information, recording of various transactions into correct transaction codes, and communication.

\section{Supervision and Monitoring}

Monitoring is the process of assessing the quality performance of the internal control structure that is implemented to achieve the objectives and is reviewed if the feasibility is no longer appropriate to the existing situation. An optimal monitoring system can

Nicholas Renaldo; Sudarno; Marice Br. Hutahuruk; Suyono; Suhardjo. Internal Control System Analysis on Account Receivables in E-RN Trading Business 
avoid the emergence of bad loans. An effective internal control structure aims at efficiency, effectiveness, and internal control over company assets and other supporting facilities. Factors that affect the implementation of good supervision and monitoring in internal control are periodic inspections, surprise inspections, and job rotation.

Internal control is an organizational plan and business method used to safeguard assets, provide accurate and reliable information, encourage and improve the efficiency of the organization's operations, and encourage conformity with established policies. Do not let there be asymmetric information between the owner and manager. Internal control includes the encouragement given to a person or employee of a certain part of the organization or the organization as a whole to run in accordance with the objectives. The internal control system includes the organizational structure, methods, and measures that are coordinated to maintain organizational wealth, check the accuracy and reliability of accounting data, promote efficiency and encourage compliance with management policies. Internal control is a series of processes or actions carried out by all members and management within the company to achieve organizational goals as expected in order to maintain company assets and ensure the efficiency of the organization's policies and procedures. The internal control system is designed to provide management with assurance that the company has achieved its goals and objectives effectively and efficiently. Control also plays an important role in detecting and preventing unwanted errors and frauds in an organization such as embezzlement, fraud, and so on.

There are several previous studies regarding the internal control of accounts receivable. Effective results were found by (Binanggal, 2016), (Desantirahayu, 2017), (Runtu \& Elim, 2016), and (Wensen et al., 2016). The opposite result was found by (Afifah, Soebandhi, \& Wardhana, 2015) and (Renaldo et al., 2020).

\section{RESEARCH METHODOLOGY}

This study uses a qualitative-quantitative approach. The variable of this research is the internal control of accounts receivable at E-RN Trading Business.

\section{Place and time of research}

This research was conducted in 2021 and the object of the research is E-RN Trading Business which is located in Pekanbaru, Riau.

\section{Data Types and Sources}

The types of data are primary data obtained directly from E-RN Trading Business staff and secondary data obtained from the second party and has been processed by the first party and observational data obtained through questionnaires.

\section{Operational Variables}

Receivables are all bills that will be paid back in the form of money from the sale of goods or services produced by the company to individual entities, companies, or other organizations.

Internal control is a process to achieve company goals that are carried out by management to provide reasonable assurance about the achievement of objectives and to ensure that the achievement of objectives is related to the effectiveness and efficiency of operations, reliability of financial reporting, and compliance with applicable laws (Renaldo et al., 2020).

\section{Data Analysis Technique}

Nicholas Renaldo; Sudarno; Marice Br. Hutahuruk; Suyono; Suhardjo. Internal Control System Analysis on Account Receivables in E-RN Trading Business 
The descriptive method is the presentation of data originating from the problems faced by the company and then an analysis is carried out by comparing the reality or practice with existing theories (Renaldo et al., 2020). Descriptive analysis, which is an analytical method by first collecting existing data then clarifying, analyzing, and then interpreting it so as to provide a clear picture of the existence being studied (Renaldo et al., 2020).

The sign test is a test that is intended to see the difference and not the magnitude of the difference and is based on the procedure on the positive (+) and negative (-) signs of the difference between pairs of ordinal data. The formula used in this research are:

Binomial Probability Distribution

$P(x)=C_{x}^{n} \pi^{x}(1-\pi)^{n-x}$

$P(x)$ : Binomial Probability if $n<10$

C : Combination

$\mathrm{x} \quad$ : Random variable defined as the number of successes or $+\operatorname{sign}(\mathrm{s})$

$\pi \quad$ : Probability of a success on each trial $(50 \%)$

Sign Test, $\mathrm{n}>10$

$z=\frac{(x \pm .50)-\mu}{\sigma}$

z : Normal Approximation to the Binomial test for sign test $n>10$

$x \quad$ : Number of plus (or minus) sign(s)

\pm .50 : Continuity correction factor: The value .5 subtracted or added, depending on the question, to a selected value when a discrete probability distribution is approximated by a continuous probability distribution.

$\mu \quad$ : Mean of the binomial distribution

$\sigma \quad$ : Standard deviation of the binomial distribution

Sign Test, $\mathrm{n}>10,+$ Signs more than $\mathrm{n} / 2$

$z=\frac{(x-.50)-.50 n}{.50 \sqrt{n}}$

z : Normal Approximation to the Binomial test for sign test $n>10$, Signs more than $\mathrm{n} / 2$

$x \quad$ : Number of plus sign(s)

-.50 : Continuity correction factor

$\mathrm{n} \quad$ : Number of observations

Sign Test, $\mathrm{n}>10,+$ Signs less than $\mathrm{n} / 2$

$z=\frac{(x+.50)-.50}{.50 \sqrt{n}}$

Nicholas Renaldo; Sudarno; Marice Br. Hutahuruk; Suyono; Suhardjo. Internal Control System Analysis on Account Receivables in E-RN Trading Business 
The Accounting Journal of BINANIAGA Vol. 06, No. 02, December 2021

p-ISSN: 2527-4309, e-ISSN: 2580-1481

$5^{\text {th }}$ Accreditation Rating: January 14, 2019 - January 13, 2024

z : Normal Approximation to the Binomial test for sign test $n>10,+$ Signs less than $\mathrm{n} / 2$

$\mathrm{x}$ : Number of plus sign(s)

+.50 : Continuity correction factor

$\mathrm{n} \quad$ : Number of observations

The hypothesis is accepted when the Sig. value $<\alpha$. Data processing will be assisted by Ms. Excel and SPSS (Renaldo et al., 2020). When the results are significant it means that the elements of internal control have been implemented effectively in the ERN Trading Business.

\section{Statistical Hypothesis}

1. The control environment for accounts receivables at E-RN Trading Business has been implemented effectively.

2. The risk assessment for accounts receivables at E-RN Trading Business has been implemented effectively.

3. The control activities for accounts receivables at E-RN Trading Business has been implemented effectively.

4. The information and communication for accounts receivables at E-RN Trading Business has been implemented effectively.

5. The supervision and monitoring for accounts receivables at E-RN Trading Business has been implemented effectively.

6. Internal control for accounts receivables at E-RN Trading Business has been implemented effectively.

\section{RESULT AND DISCUSSION}

The summary of the results of testing the effectiveness of internal control is shown in table 3.

Table 3. Summary of Test Results

\begin{tabular}{clccc}
\hline No & \multicolumn{1}{c}{ Element } & Test & Sig & Result \\
\hline 1 & Control Environment & Binomial Test & 0,262 & Not Effective \\
\hline 2 & Risk Assessment & Binomial Test & 0,227 & Not Effective \\
\hline 3 & Control Activities & Binomial Test & 0,004 & Effective \\
\hline 4 & Information and Communication & Binomial Test & 0,019 & Effective \\
\hline 5 & Supervision and Monitoring & Binomial Test & 0,867 & Not Effective \\
\hline 6 & Overall Components & Sign Test & 0,087 & Less Effective \\
\hline
\end{tabular}

Source: Processed Data, 2021

\section{Control Environment}

The results obtained from the sign test on the Control Environment show that the significance value is 0.262 , which means that the first hypotheses is rejected. This means that the control environment for accounts receivables at E-RN Trading Business has not

Nicholas Renaldo; Sudarno; Marice Br. Hutahuruk; Suyono; Suhardjo. Internal Control System Analysis on Account Receivables in E-RN Trading Business 
been implemented effectively. This is in line with research (Afifah et al., 2015; Ketaren, 2014).

This is because, in companies that still have some weaknesses that must be considered, it can be seen that there is no briefing so that employees find it difficult to express problems or opinions so that there is no discussion to solve the problems faced, employees who still do not comply with applicable regulations and policies due to sanctions. lack of firmness, lack of motivation for employees, and no segregation of duties for certain sections, thus creating a risk of irregularities in the future.

\section{Risk Assessment}

The results obtained from the sign test on the Risk Assessment show that the significance value is 0.227 , which means that the second hypothesis is rejected. This means that the risk assessment for accounts receivables at E-RN Trading Business has not been implemented effectively. This is in line with research (Afifah et al., 2015; Desantirahayu, 2017).

This is because, in companies that still have some weaknesses that must be considered, it can be seen that the company does not conduct an analysis of potential new customers or old consumers in providing credit sales so that there is no anticipation of the risk of unpaid receivables because consumers are unable to pay, customers who have Overlimit and unpaid receivables that are due can still be given credit by the supervisor because the customer is a friend or acquaintance of the supervisor or for certain reasons, there are no warnings and sanctions against consumers who do not pay their receivables, and there is no periodic review or analysis of receivables.

\section{Control Activities}

The results obtained from the sign test on the Control Activities show that the significance value is 0.004 , which means that the third hypothesis is accepted. This means that the control activities for accounts receivables at E-RN Trading Business has been implemented effectively. This is in line with research (Desantirahayu, 2017; Runtu \& Elim, 2016).

It can be seen that the control activity environment in the company with a comparison of existing theories has been going well, although there are some things that still need to be considered to continue to be evaluated.

\section{Information and Communication}

The results obtained from the sign test on the Information and Communication show that the significance value is 0.019 , which means that the fourth hypothesis is accepted. This means that the information and communication for accounts receivables at E-RN Trading Business has been implemented effectively. This is in line with research (Desantirahayu, 2017; Wensen et al., 2016).

It can be seen that the information and communication environment in the company with a comparison of existing theories has been going well, although there are some things that still need to be considered to continue to be evaluated.

\section{Supervision and Monitoring}

The results obtained from the sign test on the Supervision and Monitoring show that the significance value is 0.867 , which means that the fifth hypothesis is rejected. This means that the supervision and monitoring for accounts receivables at E-RN Trading Business has not been implemented effectively. This is in line with research (Afifah et al., 2015; Windiyah \& Putra, 2014).

This is because, in companies that still have some weaknesses that must be considered, it can be seen that the company does not stipulate a policy of rotation of

Nicholas Renaldo; Sudarno; Marice Br. Hutahuruk; Suyono; Suhardjo. Internal Control System Analysis on Account Receivables in E-RN Trading Business 
positions and sudden inspections, meetings are not often held so that problems are delayed for completion, there is no evaluation of employee compliance with established policies and procedures, and the absence of completeness and correctness checks on documents and assets in the company.

\section{Overall Components}

Overall, the internal control for accounts receivables at E-RN Trading Business has not been implemented effectively. Statistical testing shows that it is significant at ten percent alpha, but not significant at five percent, so that the implementation of internal control becomes less effective.

\section{CONCLUSIONS AND RECOMMENDATIONS}

Based on the research results, the conclusion of this research is that the control environment, risk assessment, and supervision and monitoring have not been effective in the E-RN Trading Business, but control activities and information and communication have been running effectively in the E-RN Trading Business. Overall testing shows that the implementation of the E-RN Trading Business internal control system is still less effective. follows:

Based on the conclusions of the study, the suggestions that can be given are as

1. E-RN Trading Business implements policies to limit and monitor employee actions so as not to deviate, comply with existing regulations and policies, and improve employee performance. Policies must be consistent, so that the company looks responsible and shows good service for customer satisfaction.

2. To minimize the risk of uncollectible accounts, E-RN Trading Business conducts an analysis beforehand and pays attention to receivables rather than pursuing sales targets and gives strong warnings or sanctions to consumers who do not pay their receivables that are due.

3. E-RN Trading Business regularly holds meetings after a problem is discovered and does not wait for many new problems to be held to discuss it at once.

4. E-RN Trading Business conducts unannounced checks once a week on sales, finance, and accounts receivable so that fraud does not occur.

\section{REFERENCES}

Afifah, N. N., Soebandhi, S., \& Wardhana, R. (2015). Analisis Sistem Pengendalian Internal atas Piutang pada PT GIS (Analysis of Internal Control System of Receivables at PT GIS). E-Jurnal Spirit Pro Patria, 1(1), 54-68.

Binanggal, C. V. (2016). The Internal Control Analysis of Account Receivables at PT Tunas Dwipa Matra Branch Manado. Jurnal EMBA, 4(3), 147-155.

Chandra, T., Renaldo, N., \& Putra, L. C. (2018). Stock Market Reaction towards SPECT Events using CAPM Adjusted Return. Opción, Año 34(Especial No.15), 338-374.

Desantirahayu, E. (2017). Analisis Pengendalian Intern Model "COSO" terhadap Piutang Usaha (Analysis of Internal Control Model "COSO" to Accounts Receivable). AKADEMIKA, 15(1), 14-21.

Nicholas Renaldo; Sudarno; Marice Br. Hutahuruk; Suyono; Suhardjo. Internal Control System Analysis on Account Receivables in E-RN Trading Business 
Ketaren, A. (2014). Analisis Sistem Pengendalian Internal Piutang pada Koperasi Serba Usaha (KSU) Surya Pelita (Analysis of Internal Control System Receivable to Koperasi Multi Purpose (KSU) Surya Pelita). Jurnal Ilmiah Accounting Changes, 2(2), 40-47.

Putra, R., \& Renaldo, N. (2020). Peningkatan Kepuasan Kerja dan Kinerja Guru melalui Komitmen, Budaya Organisasi, Motivasi, dan Gaya Kepemimpinan Guru SLTA Sederajat di Kabupaten Rokan Hilir. Procuratio: Jurnal IImiah Manajemen, 8(1), 125-139.

Renaldo, N., Sudarno, S., \& Hutahuruk, M. B. (2020). Internal Control System Analysis on Accounts Receivable in SP Corporation. The Accounting Journal of Binaniaga, 5(2), 73. https://doi.org/10.33062/ajb.v5i2.382

Runtu, R. D., \& Elim, I. (2016). Analysis of Internal Control Trade Receivables in PT Bussan Auto Finance (BAF) Manado. Jurnal EMBA, 4(1), 536-545.

Singal, C. R., \& Tirayoh, Vi. Z. (2015). Analisis Pengendalian Internal Piutang Usaha pada Developer Grand Kawanua International City (Analysis of Internal Accounts Receivable Control at Developer Grand Kawanua International City). Jurnal EMBA, 3(1), 286-296.

Wensen, A. C., Kawet, L., \& Saerang, I. (2016). The Analysis of Internal Control of Accounts Receivables on PT Buana Finance Tbk Manado. Jurnal EMBA, 4(3), 201208.

Windiyah, I. N., \& Putra, I. S. (2014). Analisis Pengendalian Internal pada Piutang Usaha di UD Satwa Unggul (Analysis of Internal Control on Accounts Receivable at UD Satwa Unggul). Riset Mahasiswa Ekonomi (RITMIK), 1(1), 70-87.

Nicholas Renaldo; Sudarno; Marice Br. Hutahuruk; Suyono; Suhardjo. Internal Control System Analysis on Account Receivables in E-RN Trading Business 
The Accounting Journal of BINANIAGA Vol. 06, No. 02, December 2021 p-ISSN: 2527-4309, e-ISSN: 2580-1481

$5^{\text {th }}$ Accreditation Rating: January 14, 2019 - January 13, 2024

This page intentionally be emptied

Nicholas Renaldo; Sudarno; Marice Br. Hutahuruk; Suyono; Suhardjo. Internal Control System Analysis on Account Receivables in E-RN Trading Business

Page : 92 